\title{
Corrosion, Fatigue and Corrosion Fatigue Behaviour of Metal Implant Materials, Especially Titanium Alloys
}

\author{
Claudia Fleck \\ Chair of Materials Engineering, Berlin Institute of Technology, \\ Str. des 17. Juni 135 - Sekr. EB 13, D-10623 Berlin, Germany \\ claudia.fleck@tu-berlin.de
}

Keywords: biomaterials, titanium, titanium alloys, corrosion, fatigue, corrosion fatigue

\begin{abstract}
In the last years, implant materials have gained growing importance in all areas of medicine. In the human body, materials may be exposed to high mechanical loads which comprise friction and wear besides multiaxial, multistep fatigue loading. Furthermore, the body electrolyte is very corrosive containing proteins, enzymes and cells besides salts. Basically, the success of an implant depends on the interface which develops between the implant surface and the biosystem and is determined by the surface properties of the implant material. Besides geometrical and morphological characteristics, electrochemical properties are extremely important. Generally, corrosion and fatigue tests on implant materials are performed in physiological salt solutions under strongly simplified (loading) conditions. Concerning the fatigue behaviour, it is hardly known, however, in which way the complex environmental and loading conditions in the human body influence the cyclic deformation and crack growth behaviour.
\end{abstract}

\section{Introduction}

Over the last decades, implants have become more and more important in all areas of modern medicine. First of all, the used materials have to be biocompatible which was defined as the "ability of a material to perform with an appropriate host response in a specific application" [1]. There is always some sort of interaction between the physiological environment and the foreign body. This response is strongly influenced by the surface properties of the implant material. In order to achieve long term success of an implant, a functional interface between the physiological environment and the implant has to be formed and maintained. Therefore, not only the material has to sustain the conditions in the body but also, and first of all, the physiological environment must tolerate the implant material and structure in an adequate manner.

Under physiological conditions, load bearing implants are subjected to a complex interaction of mechanical and chemical-biological loading components (comp. [2]). Cyclic loads and media containing salts in rather high concentrations besides proteins, enzymes, and cells are one aspect of the in vivo loading scheme. Generally, the mechanical properties of implants and implant materials are characterised under strongly simplified loading and environmental conditions. How much the higher complexity of the in vivo conditions comprising the mechanical loading pattern as well as the chemical-biological environment influences the fatigue life, the cyclic deformation behaviour as well as crack formation and growth - a state that must never be reached - has hardly been investigated yet. Fatigue loading and the resulting microstructural changes on the surface may strongly affect the interface to the living tissue.

Despite their physiological and mechanical relevance, microstructural investigations of the cyclic deformation behaviour of implant alloys under variable amplitude loading in the crack free fatigue state in quasi-physiological environment have scarcely been performed up to now. Especially the influence of proteins is only known roughly. The main question that arises is, how good the physiological conditions have to be simulated to achieve reliable information on the long- 
term behaviour of implant materials. In the following, the present knowledge on the corrosion, fatigue, and corrosion fatigue behaviour, mainly of titanium implant alloys, is summarised.

\section{Surface Properties of Metal Implant Materials}

Surface Oxide Layer Titanium and its alloys are appreciated as implant materials especially because of their outstanding biocompatibility and corrosion resistance. These may basically be attributed to the strongly adherent surface oxide layer of 2 to $10 \mathrm{~nm}$ thickness, mainly consisting of $\mathrm{TiO}_{2}$ [e.g. 3-10]. A further property extremely advantageous for biomedical applications is the spontaneous regeneration of the oxide layer in milliseconds even after damage in poorly oxygenated media [e.g. 11-14].

While some investigators report the oxide layer to be amorphous [15-17] others describe it to consist basically of anatase and rutile $\left(\mathrm{TiO}_{2}\right)$ with a tetragonal lattice structure $[13,14,18]$. In contrast with the passive layers formed on stainless steel or cobalt and nickel based alloys, which are electron conductive, titanium forms a semi-conducting passive layer completely ion-conducting at the potential of the physiological environment [16]. Additionally, the diffusion of metal ions or oxygen through the passive layer is slow, inhibiting redox reactions at the interface nearly completely. The reactions between biological macromolecules and the surface are controlled by the electronic structure and the resulting conductivity of the surface thereby determining the biocompatibility [19]. Such redox reactions may lead to conformational changes of biological macromolecules possibly transforming native proteins into antigens and thereby informing the immunological system to recognise an artificial material as a foreign body.

For $(\alpha+\beta)$-alloys like TiAl6V4 or TiAl6Nb7, information on the composition of the oxide layer is contradictory. Some authors report that the passive layers on titanium alloys are not different from that on pure titanium [3]. Elsewhere it is pointed out that, depending on the phase, the oxide layers on titanium alloys also contain oxides of the alloying elements [21-24]. The wettability of the oxides on cp Ti and TiAl6V4 with water, and, therefore, the surface energy, seem to be comparable according to contact angle measurements [5].

During or after implantation, the relatively thin natural surface oxide layer may be damaged due to, e.g., scratching or mechanical loading. By means of oxidation and coating methods, the chemical composition, the structure and the thickness of the oxide layers on the implant surface can be influenced to optimise the resistance against mechanical damage and, therefore, against corrosion. Well known methods are acid, thermal and anodic oxidation and the sol-gel-process [e.g. 25, 27-34]. Generally, thermal oxide layers on pure Ti, but also on Ti alloys, predominantly consist of $\mathrm{TiO}_{2}$ in the rutile structure[17, 25, 33]. For certain $\beta$ - and (near $\beta$ )-alloys, mixed oxides of Ti and special alloying elements were observed [33]. Electrochemically prepared oxide layers may be in the crystalline or amorphous state depending on the anode potential and the used electrolyte solution $[13,34]$. Scratch tests in Hanks' solution and calf serum showed that thermal oxide layers behave rather brittle with cracks and splitting near the scratch line, while anodic oxide layers deform plastically together with the substrate. During repassivation, ions of the medium were incorporated in the newly formed oxide layer and proteins were adsorbed $[35,36]$.

Corrosion Behaviour. As compared to cobalt base alloys, titanium and its alloys exhibit a superior corrosion resistance [37]. Under in vivo conditions, breakthrough of the passive layer has never been observed [38]. Pitting und crevice corrosion were neither found on implants of titanium alloys nor of cobalt base alloys [cited in 39,40] under in vivo conditions while in vitro tests in isotonic saline solution indicated a weak susceptibility of the latter material class [41]. Even though, in contrast with pure titanium, transient microscopic breakdown of the oxide layer was described to occur in titanium alloys [42]. Cp-titanium exhibits lower current densities than TiAl6V4 and several $\beta$ - and (near $\beta$ )-alloys [25]. Only the alloy TiTa30 shows a value near that of cp titanium. 
Anyway, there are reactions between the surface and the surrounding liquid which in vivo lead to a thickening of the oxide layer $[13,38]$. These reactions result in a release of species containing titanium and/or, possibly, alloying elements, into the surrounding tissue and in adsorption of oxygen containing species from the biological liquids to the surface. The corrosion resistance of $\mathrm{cp}$ titanium, the $(\alpha+\beta)$-alloy TiAl6V4 and various $\beta$ - and (near $\beta$ )-alloys can be improved by increasing the oxide thickness to around $100 \mathrm{~nm}$, independent of the oxidation procedure [25, 33].

The open circuit potential (OCP) depends strongly on the alloy composition and the surface treatment [43]. For example, the OCP of the $\beta$-alloy TiNb13Zr13 is lower than that of TiAl6V4 in the natural state but increases to a similar value after diffusion hardening. A further indicator for a high corrosion resistance is a high polarization resistance which is at least two magnitudes higher than the values observed for the stainless steel 316L and the Co-Cr-base alloy Vitallium [33, 44]. The reciprocal polarisation resistance is proportional to the rate of electron exchange and correlates well with fibrinogen retention data. The rate of electron exchange was shown to have a significant effect on the type and magnitude of interaction between fibrinogen and the surface with a greater rate of electron exchange resulting in stronger protein-surface interactions [45].

An important factor determining the corrosion resistance of titanium alloys is the microstructure, that is the phase composition and form. TiAl6 $6 \mathrm{Nb} 7$ specimens alloyed with a certain amount of Ta to improve the corrosion resistance were subjected to different heat treatments. Independent of the microstructure, all specimens remained in the passive state up to a potential of $1 \mathrm{~V}$. Nevertheless, microstructures with a more even distribution of the alloying elements had an improved corrosion resistance as compared to two-phase microstructures with pronounced differences in the content of the alloying elements.

Under physiological conditions, implants are not exposed to pure salt solutions but to protein containing serum. Nevertheless, corrosion tests on implant materials are generally performed in simulated body solutions like physiological saline, Ringer's or Hanks' solution. These simulated body solutions approximate the in vivo conditions concerning the ion strength and, possibly, the content of anorganic salts. The influence of proteins and enzymes is only considered in a very low number of investigations with sometimes contradictory results. The difference between testing in pure salt solutions or simulated body fluids containing proteins may, therefore, be important. While storage of CoCrMo-alloy powder in albumin solution resulted in selective dissolution of cobalt and molybdenum and formation of a chromium rich outer layer, the corrosion of titanium and aluminium was not influenced [38]. Other investigators report a decreased corrosion resistance of TiAl6V4 in albumin containing Ringer's solution. In a further investigation, an albumin containing $0.15 \mathrm{M} \mathrm{NaCl}$-solution caused more corrosion damage on a cast $\mathrm{CoCr}$ alloy and pure chromium than the pure salt solution [46].

\section{Fatigue Properties}

Life-oriented Investigations. The microstructure and the mechanical properties of titanium and its alloys are essentially influenced by the forming conditions and the various thermomechanical treatments. Previous work on the fatigue properties was mainly life-orientated. The influence of the microstructure, different surface treatments, the loading conditions, the temperature and different corrosive media on the endurance limit was investigated thoroughly [47-64]. For commercially pure titanium (cp-Ti), the forming conditions and the state of solution hardening are important factors determining the fatigue strength. In Fig. 1, S, N-curves for stress-controlled loading of warm formed cp-Ti grade 2, cold formed cp-Ti grade 4 and the binary alloy TiAl6V4 with a fine globular microstructure are shown [65]. Due to solution and strain hardening, the grade 4 material exhibits higher fatigue strength values as compared to the grade 2 material. As expected, the fatigue strength of the TiAl6V4 alloy is even clearly higher than for the cold formed cp-Ti grade 4. 
In the case of $(\alpha+\beta)$-alloys, globular microstructures exhibit higher endurance limits than lamellar ones [47]. Generally, however, the latter have a higher resistance against crack growth and creep failure [66]. Therefore, globular microstructures are prescribed for implant alloys. In the high cycle fatigue regime, near- $\alpha$ and $(\alpha+\beta)$ titanium alloys can be extremely mean stress sensitive [67]. This means, that the HCF endurance limit at low tensile mean stresses is much lower than expected from a linear interpolation between the fatigue strength at $\mathrm{R}=-1$ and the ultimate tensile strength $[55,56,67]$.

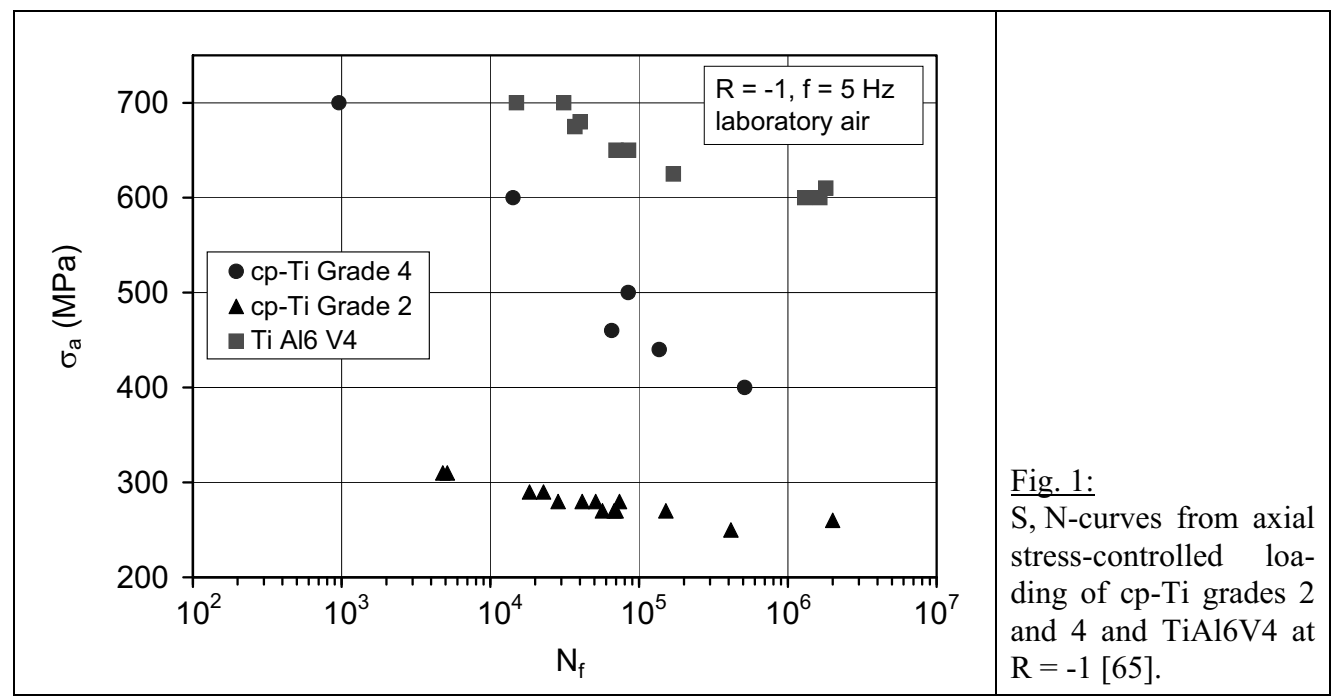

Surface hardening methods like cold rolling or shot peening induce compressive surface residual stresses which in principal increase the endurance limit and decrease the crack growth velocity. In the case of a degeneration of the residual stresses, however, the influence of the surface roughness predominates so that the endurance limit and the crack growth velocity are influenced negatively [50-53]. The endurance limit is determined by the resistance against crack formation as well as crack growth. Therefore, the mechanical properties of $(\alpha+\beta)$-titanium alloys may be specifically influenced by an appropriate combination of thermomechanical treatments and surface hardening [68].

Generally, fatigue tests on metal implant materials with different surface conditions were performed life orientated in physiological salt solutions under constant amplitude loading. Overloads, as they may occur, e.g., during stair-walking, resulted in a pronounced decrease in the fatigue life of TiAl6V4 specimens in 4-point bending tests also when the tests were performed in laboratory air [69]. Nevertheless, they are mostly not considered.

Cyclic Deformation Behaviour. Compared to life-orientated experiments, the cyclic deformation behaviour of titanium and its alloys has been examined to a much lesser extent. Cold working has a strong influence on the cyclic deformation behaviour. While hot worked cp-Ti grade 2 exhibits characteristic cyclic softening and hardening phases, cold worked cp-Ti grade 4 shows continuous softening [63]. The cyclic deformation behaviour of TiAl6V4 after different thermal treatments was examined at room and increased temperatures in [69,71-76]. Generally, the cyclic deformation behaviour of TiAl6V4 is characterised by cyclic softening $[68,70,71,73]$. The cyclic softening, the strong Bauschinger effect and the high rate of cyclic hardening in a given hysteresis loop are due to the nature of the restricted slip process in the binary TiAl6V4 alloy [70, 71]. They play an important role in the crack nucleation process. Further, cross-slip is hardly possible, which 
makes the fatigue induced microstructural changes strongly dependent on the loading history. The strongly path dependent dislocation content and behaviour result in different CSS-curves when the loading amplitude is decreased after preceding higher loading cycles.

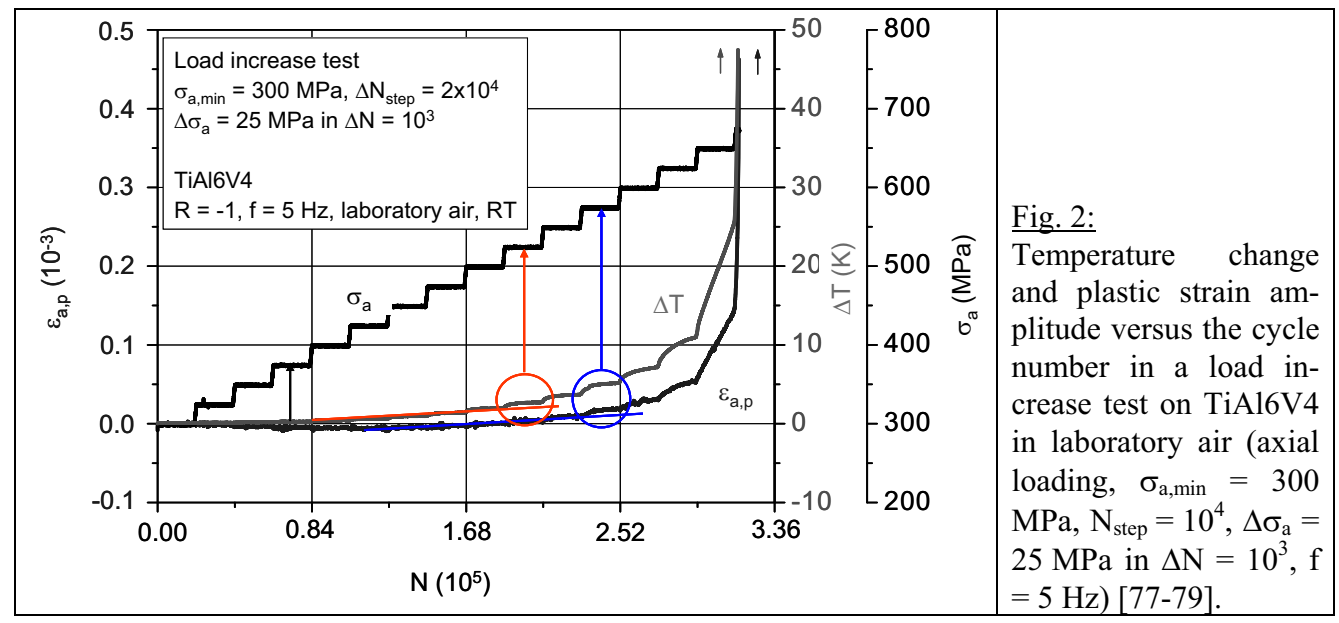

As mentioned above, temperature measurements are very well suited for characterising fatigue processes [80-82]. As compared to single step tests, load increase tests in combination with mechanical hysteresis and temperature measurements offer a good possibility to determine the cyclic yield strength of a material with a very limited number of specimens [80, 81, 83-85]. The cyclic yield strength represents an estimation value of fatigue strength as has been shown for different steels with ductile microstructures by correlating results of load increase and single step tests [81, 84]. Also for high strength materials as the steel $42 \mathrm{CrMo} 4$ in a quenched and tempered state exhibiting very small plastic deformation values, cyclic temperature curves allow the estimation of the fatigue limit while this is not possible with mechanical hysteresis measurements [85]. For high strength and brittle materials, very localised and inhomogeneous plastic deformations are often not measurable due to the integral strain measuring principle. In Fig. 2, characteristic plots of the temperature and the plastic strain amplitude versus the number of cycles are shown for TiAl6V4 [86]. The temperature change indicates microstructural damage at a much lower stress amplitude than the plastic strain amplitude does. Up to a stress amplitude of $375 \mathrm{MPa}$ hardly any change of the temperature can be observed. This initial phase is followed by a slight temperature increase which can be fitted by a linear function. When the stress amplitude is increased to $\sigma_{\mathrm{a}}=525 \mathrm{MPa}$ the temperature increases more intensely due to intensified plastic deformation processes. From $\sigma_{\mathrm{a}}=575 \mathrm{MPa}$ onwards, the temperature increase is even more pronounced. As outlined above, this pronounced temperature increase at $\sigma_{\mathrm{a}}=575 \mathrm{MPa}$ yields an estimation value for the cyclic yield strength which itself can be used to estimate the endurance limit [80,81]. At the beginning of loading the plastic strain amplitudes are very small in the range of the resolution of the capacitive strain sensor. A more pronounced increase in the plastic strain amplitude is first observed for a stress amplitude of $575 \mathrm{MPa}$. The evaluation of the temperature- and plastic strain amplitudecurves yielded an estimation value for the endurance limit of TiAl6V4 for loading in laboratory air of $\mathrm{R}_{\mathrm{D}, \mathrm{LIT}}=600 \mathrm{MPa}$. For TiAl6Nb7 the estimation value was $650 \mathrm{MPa}$.

The SEM and TEM micrographs in Figs. 3 and 4, respectively, show the very fine, equiaxed microstructure according to DIN ISO 5832 part 3 which only slightly differs in the transversal and longitudinal direction. As proven by energy dispersive X-ray analysis, the small grain in the centre of the TEM micrograph in Fig. 4 a is a $\beta$ grain surrounded by different grains of the $\alpha$ phase. A 
grain boundary can be seen in the upper left part of the micrograph. The microstructure of the TiAl6Nb7-alloy is shown in the SEM and TEM micrographs below (Figs. 5, $\underline{6}$ ). In the Nbcontaining alloy, the grains of the $\beta$ phase are more stretched as compared to the V-alloyed one. This difference is even more obvious in the TEM micrographs.
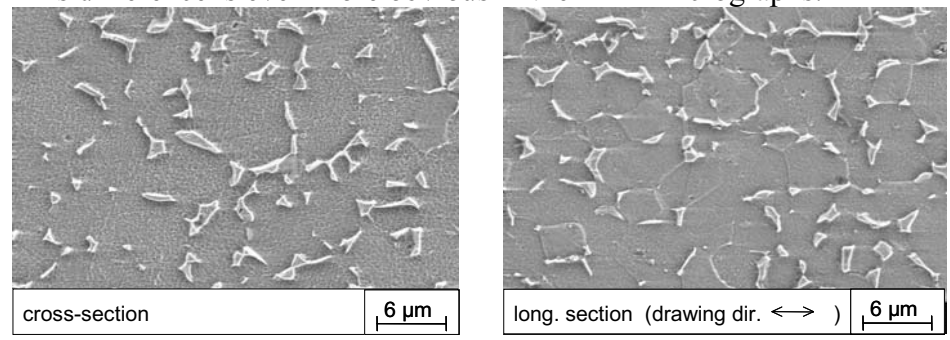

Fig. 3:

SEM: Fine globular microstructure of the alloy TiAl6V4 [77-79].
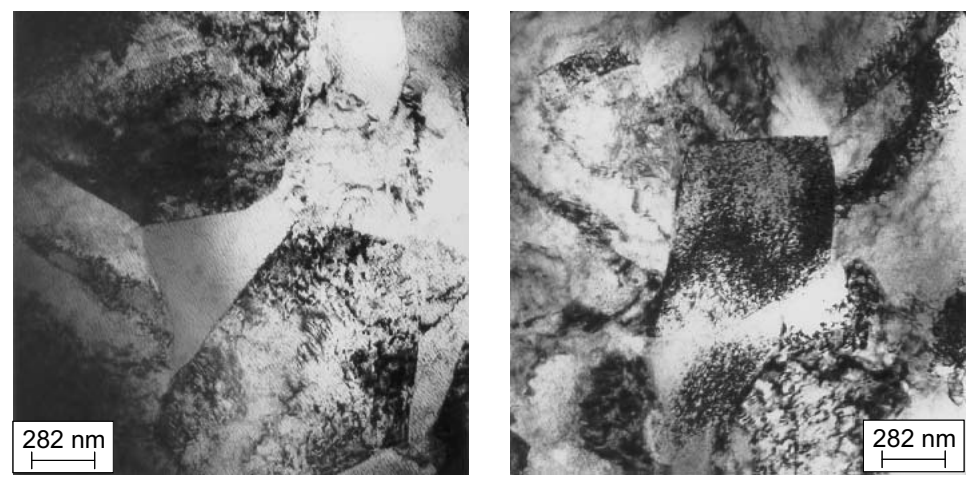

Fig. 4:

TEM: Cross-section of TiAl6V4 with a fine globular microstructure $[79,86]$
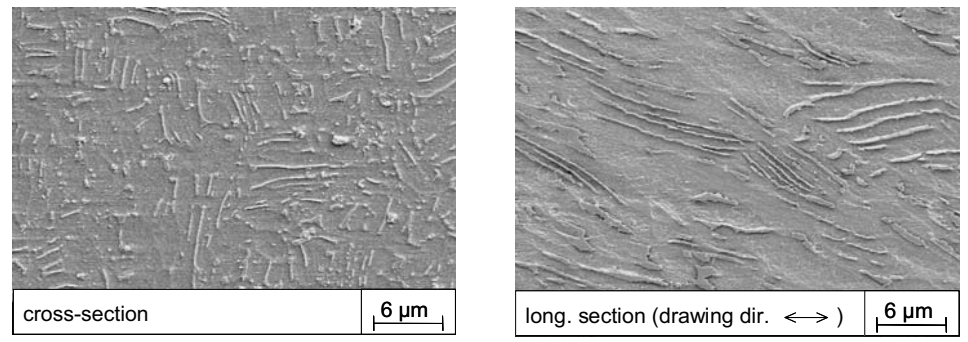

Fig. 5:

SEM: Fine globular microstructure of the alloy TiAl6Nb7 [77-79].
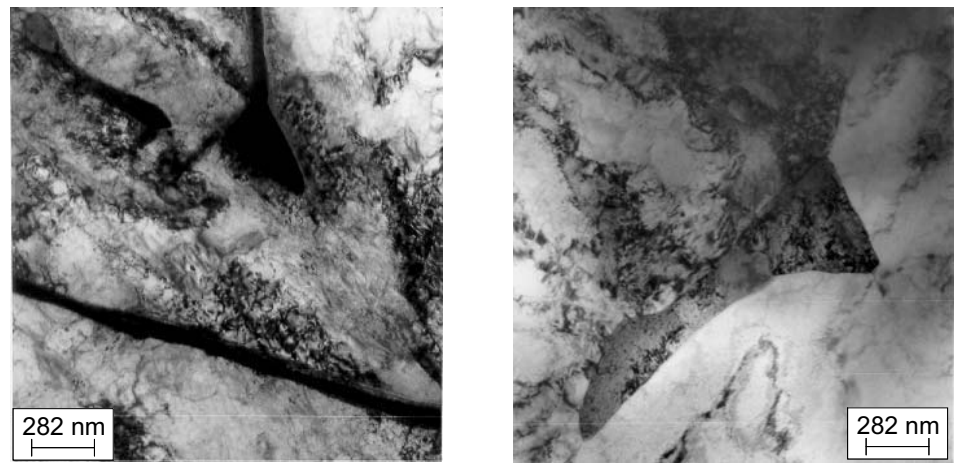

Fig. 6:

TEM: Cross-section of TiAl6Nb7 with a fine globular microstructure $[79,86]$. 
Microstructural Investigations of Fatigue Damage. Microstructural fatigue damage was examined by light and scanning electron microscopy for defined fatigue states and after specimen failure and correlated with the measured development of the hysteresis parameters as well as the temperature [87]. Figure 7 shows the surface of a TiAl6V4 specimen axially tested in a stepwise load increase test in laboratory air. When replicas indicated surface damage at a stress amplitude of $600 \mathrm{MPa}$, the test was interrupted and the specimen surface was examined by scanning electron microscopy. Besides marks originating from the mechanical polishing procedure, deformation lines were observed parallel and under an angle of about $30^{\circ}$ towards the long axis of the specimen and the loading direction, respectively. XRD measurements revealed a slight $\langle 10 \overline{1} 0\rangle$ texture of the $\alpha$ phase nearly parallel to the longitudinal rod axis which is due to the combined cold and warm drawing process during fabrication. The c-axis of the hexagonal unit cell is inclined by $70^{\circ}$ versus the longitudinal rod axis thereby lying vertical to the rod surface along the rod diametre. The prevalent orientation of the slip bands corresponds to the measured texture of the material and the slip systems of the hexagonal lattice structure.

\begin{tabular}{|c|c|c|c|}
\hline $2 \mu \mathrm{m}$ & $2 \mu \mathrm{m}$ & $2 \mu \mathrm{m}$ & Fig. 7: \\
\hline$x$ & & & $\begin{array}{l}\text { structural damage on } \\
\text { the surface of TiAl6V4 } \\
\text { (load in-crease test, } \mathrm{R}= \\
-1, \mathrm{f}=5 \mathrm{~Hz}, \text { labor. air, } \\
\mathrm{RT}, \sigma_{\mathrm{a} \text {, } \min }=100 \mathrm{MPa} \text {, } \\
\mathrm{N}_{\text {step }}=10^{4}, \Delta \sigma_{\mathrm{a}}=50\end{array}$ \\
\hline $\begin{array}{l}\sigma_{\mathrm{a}}=600 \mathrm{MPa} \\
\mathrm{N}=9.8 \cdot 10^{4}\end{array}$ & $\begin{array}{l}\sigma_{a}=650 \mathrm{MPa} \\
\mathrm{N}=1.1 \cdot 10^{5}\end{array}$ & $\begin{array}{l}\sigma_{a}=650 M P a \\
N_{f}=1.2 \cdot 10^{5}\end{array}$ & $\begin{array}{l}\mathrm{MPa} \text { in } \Delta \mathrm{N}=10^{3}, \\
\text { loading direction } \leftrightarrow \text { ) }\end{array}$ \\
\hline
\end{tabular}

\section{Corrosion Fatigue Properties}

Fatigue Life Behaviour. Fig. 8 shows S, N-curves for stress-controlled axial loading of cp-Ti grade 4 in laboratory air and Ringer's solution [65]. For stress amplitudes lower than about $500 \mathrm{MPa}$, loading in Ringer's solution results in a distinct reduction of fatigue life as compared to laboratory air. In the range of finite fatigue lives, the S, N-curve further exhibits a much higher slope. As expected, the influence of the Ringer's solution therefore becomes stronger with increasing fatigue life. As shown above for laboratory air, the $(\alpha+\beta)$-alloys TiAl6 Nb7 and TiAl6V4 generally show higher fatigue limits as compared to the cp-Ti grades $[77,78]$.

While physiological saline solution did not decrease the fatigue lifetime of TiAl6V4 and TiAl5Fe2.5 specimens in rotating bending tests, the lifetime of TiAl5Fe2.5 specimens was decreased after implantation in the soft tissue of rabbits for eleven months. The authors attributed this to the lower oxygen content in the tissue as compared to oxygen saturated testing media as specimens tested in Ringer's solution saturated with nitrogen instead of oxygen exhibited lower fatigue strength values as compared to specimens tested in air or oxygen saturated Ringer's solution [88]. The decrease in fatigue strength became apparent for fatigue lives higher than about $2 \times 10^{5}$ cycles and was even more pronounced for fatigue lives higher than 2 x $10^{6}$ cycles. This clearly indicates a corrosion process acting together with the mechanical loading as repassivation of damaged surface areas is not possible in the nitrogen saturated medium. However, in the case of the implanted specimens, they must have experienced some sort of surface damage or change during implantation in the absence of mechanical loading which then was detrimental to their mechanical stability during cyclic loading in an oxygen saturated environment. 


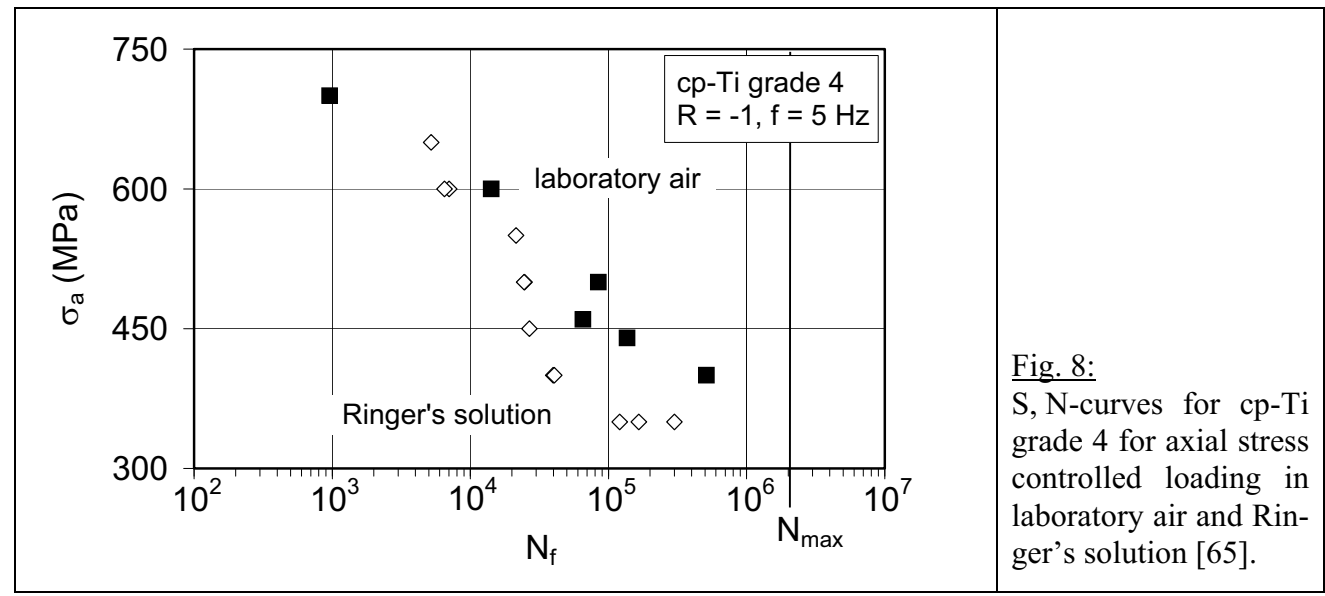

Cyclic Deformation Behaviour. While fatigue life data are readily attained from rotating bending tests, information concerning the cyclic deformation behaviour of the specimens cannot easily be yielded. For testing in corrosive media, corrosion potential measurements are very suitable to gain information on surface damage. Under equilibrium conditions, passivating materials like titanium and its alloys exhibit a constant free corrosion potential in electrolyte solutions. At the beginning of testing, the measured value actually is the free corrosion potential of the oxide layer in oxygen saturated Ringer's solution. This potential was measured by an Argenthal electrode adapted to a Haber-Luggin capillary. As long as no surface reactions take place the free corrosion potential stays constant. The possible potential changes under cyclic loading in corrosive media depend on two competing processes $[65,89]$. The generation of new surfaces due to the development of slip bands and/or crack formation and growth shifts the corrosion potential towards more negative values. Repassivation occurs instantaneously resulting in a return of the potential towards more positive values. The actual value of the corrosion potential is, therefore, determined by the relative velocities of the formation of new surface and its repassivation. The velocity of the repassivation itself depends on the kinetics of the metal surface reactions and the conditions for oxygen access. Predecessing tests showed that surface damage, in contrast to scattering effects, is indicated by a sharp decrease in corrosion potential followed by an exponential recovery. Changes in potential as small as $10 \mathrm{mV}$ clearly indicate microstructural damage.

Axial tests on TiAl6V4 and TiAl6Nb7 with a fine globular microstructure in oxygen-saturated Ringer's solution exhibited very small plastic strain amplitudes due to the high strength of both alloys [77-79]. In dependence on the stress amplitude and the development of the plastic strain amplitude, the cyclic deformation curves can be classified into three groups. As expected in the transition range of the $\mathrm{S}, \mathrm{N}$-curve, specimens which reached $2 * 10^{6}$ cycles without failure showed very low values of the plastic strain amplitude $\left(\varepsilon_{\mathrm{a}, \mathrm{p}}<\approx 0,05 \%\right)$ over the whole loading time. At higher stress amplitudes, TiAl6V4 exhibits an initial softening followed by a hardening phase. For TiAl6 Nb7 certain medium stress amplitudes lead to a saturation state of the plastic strain amplitude over the greatest part of fatigue life followed by a slight softening shortly before final failure. For even higher stress amplitudes both alloys show pronounced and continuous cyclic softening until specimen failure.

Under physiological conditions, implants are not exposed to pure salt solutions but to protein containing serum. This difference is important as an influence of proteins on the corrosion resistance was reported for different implant materials [e.g. 44]. In load increase tests on TiAl6V4 and $\mathrm{TiAl6Nb7}$ with a fine globular microstructure, no influence of the medium on the fatigue 
behaviour and the estimated endurance limit could be detected $[77,78]$. However, this may be due to the rather short testing times in the load increase tests. The influence of proteins being a corrosion effect may possibly only show after longer exposure times.

Microstructural Investigations. Figure 9 shows a typical fatigue crack on the surface of an axially loaded specimen of cp-Ti grade 4 detected by a potential drop [65]. In the area of the crack tip slip bands can be clearly seen. During rotating bending in corrosive environment, corrosion potential measurements are very suitable to gain information on surface damage. Even specimens that did not fail after $2 \cdot 10^{6}$ cycles exhibit microcracks in the outermost surface (Fig. 10). Figure 11 shows the surface of a specimen loaded with a surface stress amplitude of $680 \mathrm{MPa}$. When the corrosion potential had decreased by around $26 \mathrm{mV}$ and $47 \mathrm{mV}$, the test was interrupted. A crack of about $200 \mu \mathrm{m}$ length normal to the loading direction was observed by light microscopy after the first interruption. It had grown to about $400 \mu \mathrm{m}$ after the second interruption. The crack growth behaviour on the surface of a TiAl6 Nb7 specimen during rotating bending in Ringer's solution is shown in Fig. 12. In the area of the presumed crack origin (bottom left), the surface of the specimen shows distinct signs of reaction with the surrounding medium. It may be assumed that this area was activated due to strain localisation. At the crack tip, crack branching occurs (top right) and plastic deformation marks are visible (bottom right). Loading in calf serum leads to even stronger surface reactions (Fig. 13).

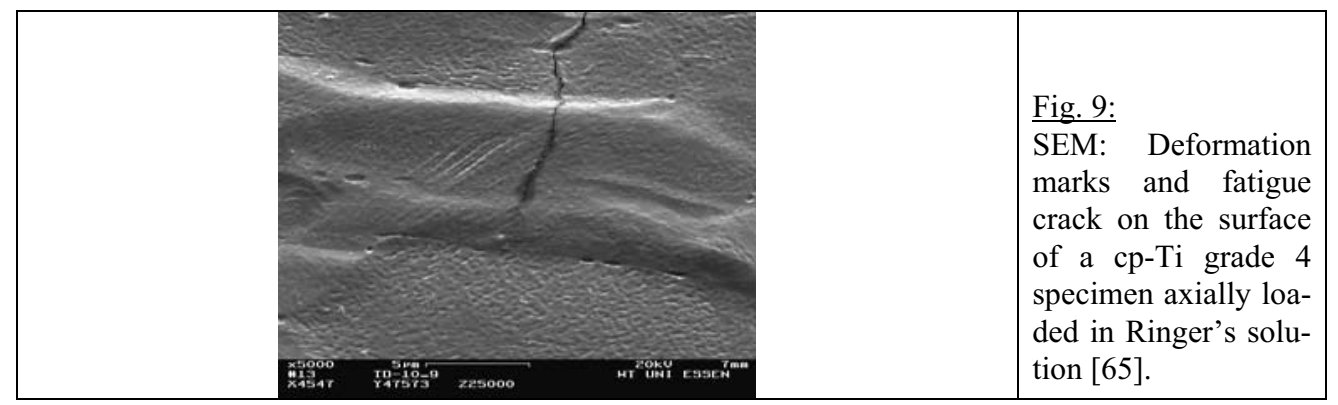

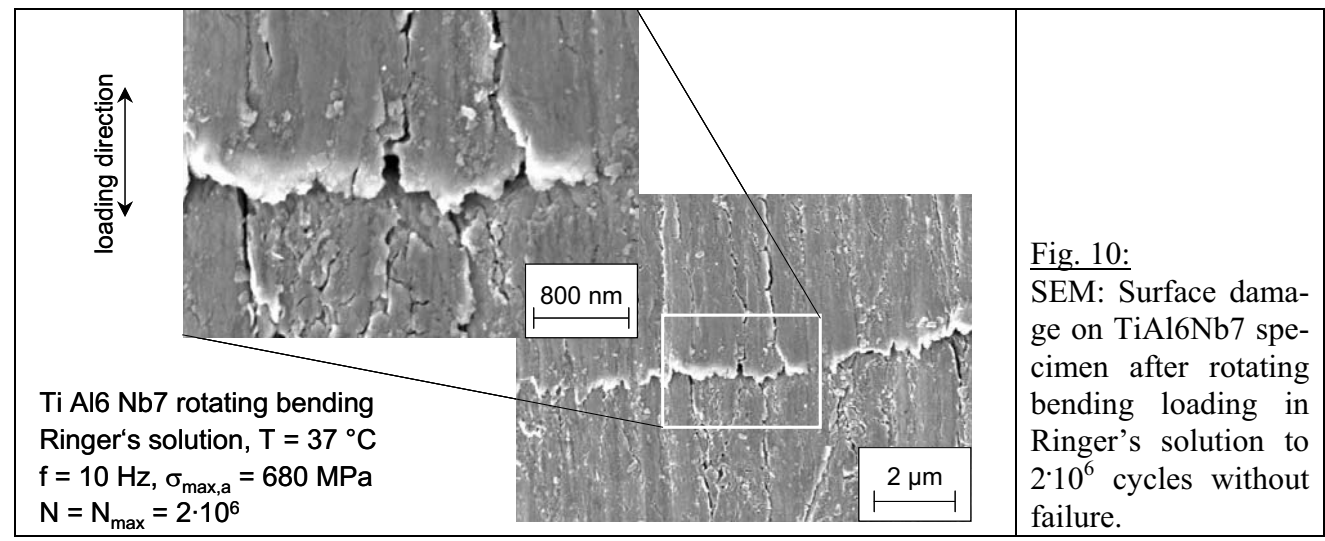




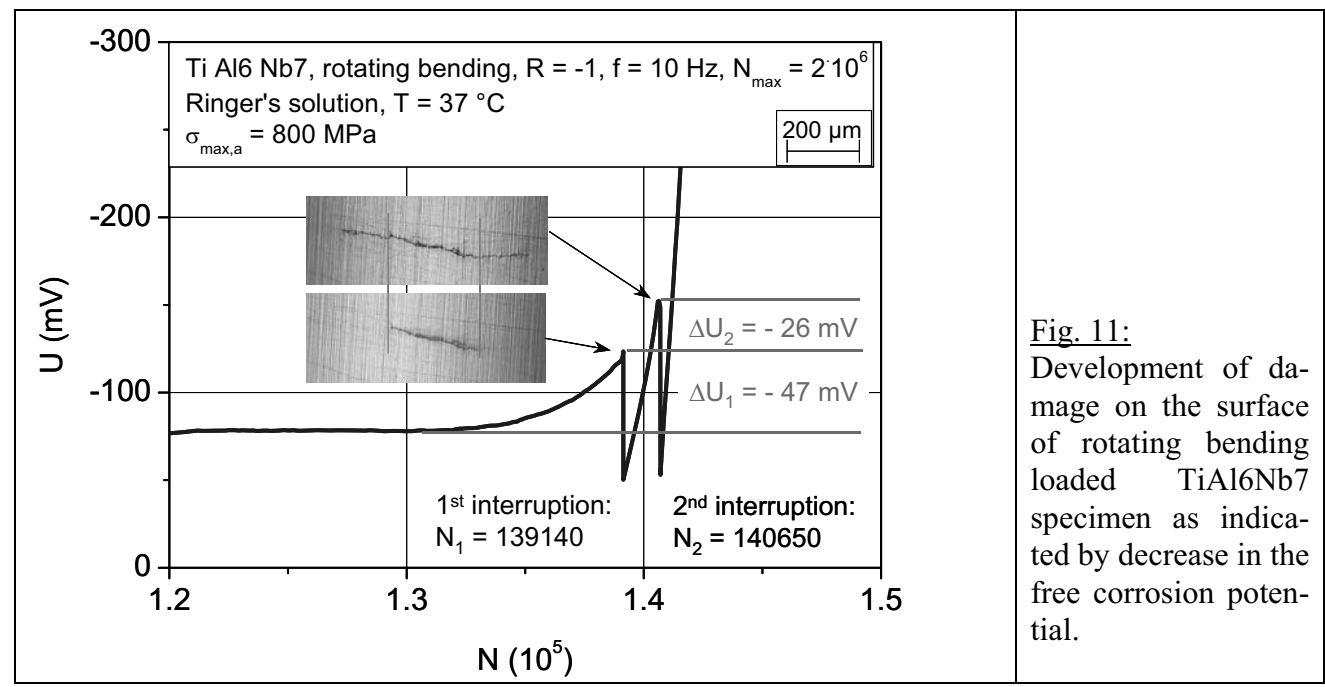

\begin{tabular}{|l} 
Ti Al6 Nb7 \\
rotating bending \\
$\begin{array}{l}\mathrm{T} \text { Tinger's solution } \\
\mathrm{T}=37^{\circ} \mathrm{C}\end{array}=10 \mathrm{~Hz}$ \\
$\sigma_{\text {max,a }}=800 \mathrm{MPa}$ \\
$\mathrm{N}=139140$
\end{tabular}

\section{Conclusions}

Permanent implants are meant to replace the function of a part of the body for the lifetime of the patient. The long term behaviour of load bearing implants is influenced, on the one hand, by the reaction of the body to this foreign object, and, on the other hand, by the mechanical behaviour of the implant and the surrounding tissue. The key issue is the interface between the implant and the tissue with the aim of a long lasting, intricate bond between the two. To achieve this, several aspects have to be considered. The biological-chemical and the mechanical stability of the implant materials have to be characterized and optimized with respect to the requirements of the physiological system. The environmental and loading conditions in the body are rather severe and extremely different from the general conditions during laboratory testing. High cyclic loads have to be sustained in an aggressive environment containing salts, enzymes, and proteins. As these conditions affect the implant surface and thereby the formation and long-term stability of the interface to the biological system, the corrosion, fatigue and corrosion fatigue behaviour of titanium alloys have been reviewed with respect to the influence of these different conditions. 


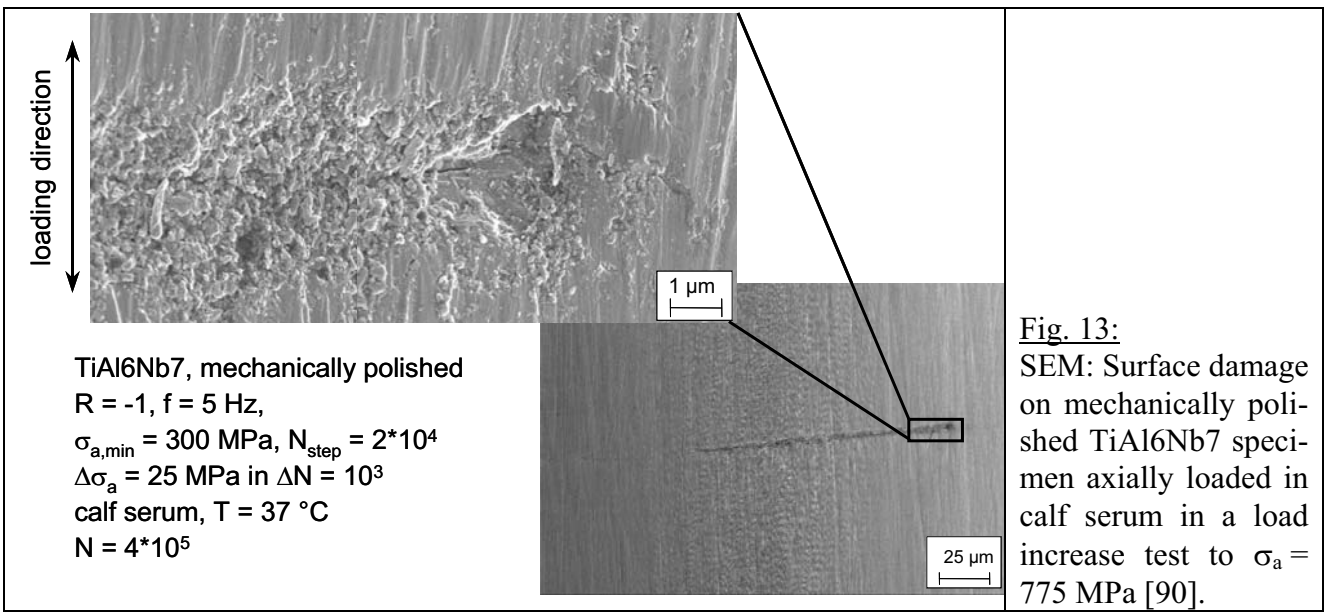

\section{Acknowledgements}

The experimental work was performed during the author's time at the Department of Materials Science of the Technical University Kaiserslautern, Germany. The author greatly acknowledges the support of her supervisor Prof. Dr.-Ing. D. Eifler and of her diploma and PhD students Dr.-Ing. C. Leinenbach, Dipl.-Ing. K. Rau, and Dr.-Ing. B. Schwilling.

\section{References}

[1] D.F. Williams, in: Advances in Biomaterials, C. de Putter, K. de Lange, K. de Groot, A.J.C. Lee (eds.), Elsevier Science Publishers B.V., Amsterdam (1988) 11-16

[2] C. Fleck, in: Verschleißbeständige Oberflächen für Verkehrstechnik, Maschinenbau und Medizintechnik, Proc. 28. Ulmer Gespräch, 18./19.05.2006, Neu-Ulm, Fachausschuss Forschung der DGOT e.V., Eugen G. Leuze-Verlag, Saulgau (2006) 127-135

[3] M. Schmidt, Osteologie 1(4) (1992) 222-235

[4] R. Thull, DGM Fortbildungsseminar Biomaterialien, Saarbrücken, October 8-10, 1995

[5] J.C. Keller, C.M. Stanford, J.P Wightman, R.A. Draughn, R. Zaharias, J. Biomed. Mat. Res. 28 (1994) 939-946

[6] J.L. Ong, L.C. Lucas, G.N. Raikar et al., J. Mat. Sci.: Mat. in Med. 6 (1995) 113-119

[7] G.N. Raikar, J.C. Gregory, J.L. Ong L.C. Lucas, J.E. Lemons, D. Kawahara, M. Nakamura, J. Vac. Sci. Techn. A 13 (1995) 2633-2637

[8] D. Kawahara, J.L. Ong, G.N. Raikar et al., Int. J. Or. Impl. 11 (1996) 435-442

[9] J. Lausmaa, J. El. Spectr. Rel. Phen. 81 (1996) 343-361

[10] B. Kasemo, J. Lausmaa, in: Tissue Integrated Prostheses: Osseointegration in Clinical Practice, P.-I. Branemark, G.A. Zarb, T. Albrektsson (Eds.): Quintessence, Chicago (1985) 99

[11] V. Wadewitz, J. Breme, Zeitschr. Zahnärztl. Impl. 5 (2) (1989) 116-120

[12] E.A.B. Effah, P.D. Bianco, P. Ducheyne, J. Biomed. Mater. Res. 29 (1995) 73-80 
[13] J.E. Ellingsen, Biomat. 12 (1991) 593-596

[14] T. Hanawa, K. Asami, K. Asaoka, J. Biomed. Mater. Res. 40 (1998) 530-538

[15] J.L. Ong, L.C. Lucas, G.N. Raikar, et al, J. Mat. Sci.: Mat. in Med. 6 (1995) 113-119

[16] D. Scharnweber, in: Metals as Biomaterials, J.A. Helsen, H.J. Breme (Eds.):, John Wiley \& Sons Ltd., Chichester, England (1998) 101-151

[17] E. Bess, R. Cavin, K. Ma, J.L. Ong, Impl. Dent. 8(2) (1999) 126-132

[18] R. Thull, Implantatwerkstoffe für die Endoprothetik, Fachverlag Schiele \& Schön GmbH, Berlin (1978)

[19] R. Thull, in: Metals as Biomaterials, J.A. Helsen, H.J. Breme (Eds.): John Wiley \& Sons Ltd., Chichester, England (1998) 291-315

[20] A.F. Hollemann, E. Wiberg, Lehrbuch der anorganischen Chemie, Walter de Gruyter, Berlin (1976)

[21] K. Schenk-Meuser, H. Duschner, V. Biehl, E. Eisenbarth, J. Breme, Surf. Int. An. 30 (2000) 29-31

[22] P.-A. Mäusli, P.R. Bloch, V. Geret, S.G. Steinemann, in: Biological and Biomechanical Performance of Biomaterials, P. Christel, A. Meunier, A.J.C. Lee (Eds.): Elsevier Science Publishers B.V., Amsterdam (1986) 57-62

[23] P.-A. Mäusli, J-P. Simpson, G. Burri, S.G. Steinemann, in: Implant Materials in Biofunction, Advances in Biomaterials Vol. 8, C. de Putter, G.L. de Lange, K. de Groot, A.J.C. Lee (Eds.): Elsevier Science Publishers B.V., Amsterdam (1988) 305-310

[24] J. Lausmaa, M. Ask, U. Rolander, B. Kasemo, Materials Research Society Symp. Proc. 110 (1989) 647-653

[25] D. Velten, V. Biehl, E. Aubertin, B. Valeske, W. Possart, J. Breme, J. Biomed. Mater. Res. 59 (2002) 18-28

[26] J. Muscat, V. Swamy, N.M. Harrison, Phys. Rev. B, Vol. 65 (2002) 224112-1 - 224112-15

[27] R. Hazan, R. Brener, U. Oron, Biomat. 8 (1993) 570-574

[28] S.F. Xie, Key Eng. Mat. 20-28 (1988) 397

[29] M. Ask, U. Rolander, J. Lausmaa, B. Kasemo, J. Mat. Res. 5(8) (1990) 1662-1667

[30] B. Gasser, A. Frenk, Galvanotechn. 51 (1997) 88

[31] H. Nygren, P. Tengvall, I. Lundström, J. Biomed. Mat. Res. 34 (1997) 487-492

[32] H.-P. Tümmler, Oberflächeneigenschaften von Titan und Tantal für Implantate, Dissertation, Friedrich-Alexander-Universität Erlangen-Nürnberg (1986)

[33] D. Velten, K. Schenk-Meuser, V. Biehl, H. Duschner, J. Breme, Zeitschr. Metallkd. 94-6 (2003) 667-675

[34] B. Wälivaara, B.J. Aronsson, M. Rodahl, J. Lausmaa, P. Tengvall, Biomat. 15(10) (1994), $827-834$

[35] C. Leinenbach, C. Fleck, D. Eifler, Mat.wiss. u. Werkst.techn. 33-8 (2002) 442-447

[36] C. Leinenbach, C. Fleck, D. Eifler, Proc. 3. Tagung DVM-Arbeitskreis „Biowerkstoffe“, 12./13.04.2002, Köln, DVM, Berlin (2002) 21-29

[37] J. Breme, Mémoires et Études Scientifiques Revue Métallurgie Octobre (1989) 625-638 
[38] G.C.F. Clark, D.F. Williams, J. Biomed. Mat. Res. 16 (1982) 125-134

[39] E. Wintermantel, S.-W. Ha, Biokompatible Werkstoffe und Bauweisen: Implantate für Medizin und Umwelt, 2., völlig neu bearbeitete Auflage, Springer-Verlag Berlin Heidelberg New York (1998)

[40] K. Nielsen, Br. Corros. J. 22(4) (1987) 272-278

[41] C.G. Griffin, R.A. Buchanan, J.E. Lemons, J. Biomed. Mat. Res. 17 (1983) 489-500

[42] M.F. Semlitsch, F. Staub, H. Weber, Proc. of the 5th European Conference on Biomaterials (1986) 69-74

[43] Y.H. Yun, V.T. Turitto, K-P. Daigle, P. Kovacs, J.A. Davidson, S.M. Slack, J. Biomed. Mat. Res. 32 (1996) 77-85

[44] H. Zitter, J. Plenk, J. Biomed. Mat. Res. 21(7) (1987) 881-896

[45] A. Bolz, M. Schaldach, Med. \& Biol. Eng. \& Comp. 31 (1993) S123-S130

[46] H. Tomas, A.P. Freire, L.M. Abrantes, J. Mat. Sci.: Mat. in Med. 5 (1994) 446-451

[47] H.E. Franz, W. Scharfenberger, G. Fey, Mat.wiss. u. Werkst.techn. 25 (1994) 399-409

[48] H.E. Franz, W. Scharfenberger, G. Fey, Mat.wiss. u. Werkst.techn. 25 (1994) 399-409

[49] L. Wagner, J.K. Gregory, Advanced Materials and Processes 3 (1994) 36u-36z

[50] W. Calles, Einfluss der Randschichtverformung durch Kaltrollen und Kugelstrahlen auf die Schwingfestigkeit der Titanlegierung TiAl6V4, Dissertation, Rhein.-Westf. Hochschule Aachen (1985)

[51] T. Hirsch, Zum Einfluss des Kugelstrahlens auf die Biegeschwingfestigkeit von Titan- und Aluminiumbasislegierungen, Dissertation, Universität Karlsruhe (TH) (1983)

[52] H. Hanagarth, Auswirkung von Oberflächenbehandlungen auf das Ermüdungsverhalten von TiAl6V4 und 42CrMo4 bei erhöhter Temperatur, Dissertation, Universität Karlsruhe (TH) (1989)

[53] L. Wagner, Mikrorissausbreitung in hochfesten Titan- und Aluminiumlegierungen, Habilitationsschrift, Technische Universität Hamburg-Harburg (1989)

[54] L. Wagner, J.K. Gregory, Adv. Mat. Proc. 7 (1994) 50HH-50JJ

[55] J. Lindemann, A. Berg, L. Wagner, in: Fatigue '96 - Proceedings of the $6^{\text {th }}$ International Fatigue Congress, Berlin, G. Lütjering, H. Nowack (Eds.), Pergamon (1996) Vol. I 203-208

[56] J. Lindemann, L. Wagner, Mat. Sci. Eng. A234-236 (1997)1118-1121

[57] S. Adachi, L. Wagner, G. Lütjering, Proc. $7^{\text {th }}$ International Conference on Strength of Metals and Alloys, Montreal, 12.-16.08.1985, Toronto (1985) 2117-2122

[58] J. Broichhausen, M. Telfah, Metall 34 Nr. 10 (1980) 909-917

[59] M.A. Imam, C.M. Gilmore, Metall. Trans. A 14A (1983) 233-240

[60] M. Hempel, Draht 15(8) (1964) 502-514

[61] M. Hempel, Draht 16(4) (1965) 209-217

[62] M. Hempel, Draht 16(10) (1965) 716-726

[63] M. Hempel, Draht 17(4) (1966) 206-218

[64] M. Hempel, E. Hillnhagen, Archiv für das Eisenhüttenwesen 37 (1966) 263-274 
[65] C. Fleck, P. Göbbeler, D. Eifler, Proc. 1. Tagung DVM-Arbeitskreis „Biowerkstoffe“, 24./25.04.1998 Berlin, DVM, Berlin (1998) 65-74

[66] L. Wagner, J.K. Gregory, Adv. Mat. Proc. 3 (1994) 36w-36z

[67] L. Wagner, ASM Handbook Vol. 19, Fatigue and Fracture (1996) 837-845

[68] L. Wagner, J.K. Gregory, Adv. Mat. Proc. 7 (1994) 50HH-50JJ

[69] C.M. Styles, S.L. Evans, P.J. Gregson, in: Fatigue '96 - Proceedings of the 6th International Fatigue Congress, Berlin, G. Lütjering, H. Nowack (Eds.), Pergamon (1996) Vol. III 17991804

[70] R.K. Steele, A.J. McEvily, Proc. International Conference on Fracture Mechanics and Technology - Proceedings, Hongkong March 21-25, 1977, Alphen a.d. Rijn (1977) 33-51

[71] R.K. Steele, A.J. McEvily, Eng. Fract. Mech. 8 (1976) 31-37

[72] P. Lukas, M. Klesnil, J. Polak, Mat. Sci. Eng. 15 /1974) 239-245

[73] Chr. Boller, T. Seeger, Materials Data for Cyclic Loading, Part D: Aluminium and Titanium Alloys, Materials Science Monographs, 42 D, Elsevier, Amsterdam Oxford New York Tokyo (1987) 130-140

[74] M.A. Däubler, Mikrostruktur und mechanische Eigenschaften von Titanlegierungen, Dissertation, Ruhr-Universität Bochum (1980)

[75] C.C. Wojcik, D.A. Koss, Mat. Sci. Eng. 27 (1977) 97-99

[76] T. Bui-Quoc, R. Gomuc, A. Biron, Trans. ASME J. Eng. Mat. Techn. Vol. 114 October (1992) 390-398

[77] B. Schwilling, C. Fleck, D. Eifler, Mat.wiss. u. Werkst.techn. 33-8 (2002) 453-458

[78] B. Schwilling, C. Fleck, D. Eifler, Proc. 3. Tagung DVM-Arbeitskreis „Biowerkstoffe“, 12./13.04.2002, Köln, DVM, Berlin (2002) 41-51

[79] B. Schwilling, C. Fleck, D. Eifler, Z. Metallkd. 93-7 (2002) 620-626

[80] A. Piotrowski, D. Eifler, Mat.wiss. u. Werkst.techn. 26 (1995) 121-127

[81] H. Harig, K. Middeldorf, K. Müller, Härterei Techn. Mitt. 41(5) (1986) 286-296

[82] K. Stärk, Thermometrische Untersuchungen zum zyklischen Verformungsverhalten metallischer Werkstoffe, Dr.-Ing. Dissertation Universität Stuttgart (1980)

[83] D. Dengel, H. Harig, Materialprüfung 22(3) (1980) 120-130

[84] H. Harig, Proc. VDEh-Tagung „Werkstoffprüfung 1988“, DVM, Berlin (1988)

[85] K. Middeldorf, H. Harig, Härterei Technische Mitteilungen 42(1) (1987) 34-41

[86] B. Schwilling, C. Fleck, D. Eifler, Bericht DFG-Forschungsvorhaben Fl 316/2-1 (2002)

[87] C. Fleck, D. Eifler, Adv. Eng. Mat. (2000)

[88] M. Niinomi, T. Kobayashi, O. Toriyama, N. Kawakami, Y. Ishida, Y. Matsuyama, in: Fatigue '96 - Proceedings of the 6th International Fatigue Congress, Berlin, G. Lütjering, H. Nowack (Eds.), Pergamon (1996) Vol. III 1805-1810

[89] P. Göbbeler, D. Eifler, Proc. DVM-Werkstoffprüfung 95, Bad Nauheim, DGM Informationsgesellschaft, Frankfurt / Main (1995) 151-160

[90] C. Leinenbach, C. Fleck, D. Eifler, unpublished results 